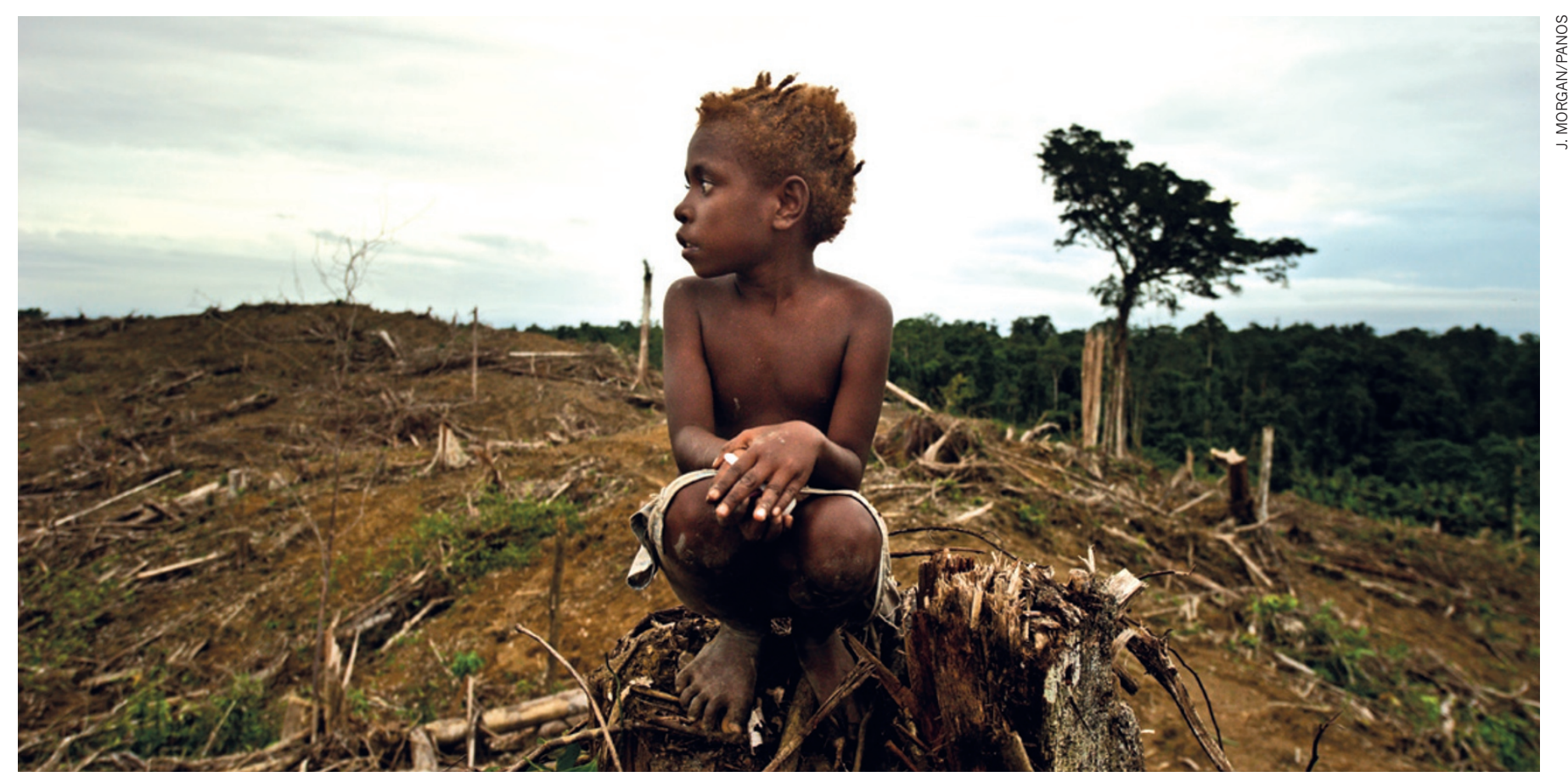

An Indonesian child surveys ancestral lands logged to make way for an oil-palm plantation — just one example of 'land-grabbing' by outside concerns.

DEVELOPMENT

\section{Striking out for new territory}

\section{Wendy Wolford hails a perceptive take on the people and organizations behind modern big land acquisitions.}

\section{$\mathrm{L}$}

eo Tolstoy asked an eerily prescient question in his 1886 short story How Much Land Does a Man Need? That question and its answer - enough to bury a coffin, said Tolstoy - are captured perfectly in the compelling and well-researched The Landgrabbers. In it, science journalist Fred Pearce dissects the modern rush to acquire land for production, investment, speculation or preservation, focusing on the people and organizations with the will, and the money, to do it.

The amount of land being bought and sold worldwide has increased by a factor of at least ten in the past five to ten years, according to the World Bank. The international community became acutely aware of the scale of acquisitions in 2009, after the South Korean firm Daewoo Logistics entered a deal to buy one-third of the arable land in Madagascar - one of the world's poorest countries - to grow palm oil and maize (corn). There was widespread protest leading to a change in Malagasy government and the deal fell through but hundreds more continue. Media and scholarly attention to the issue is increasing. Yet understanding of these deals is still sketchy. Pearce points out that it is nearly impossible to quantify land acquisition accurately. What we do know is that land deals have complex drivers, including increasingly volatile food and fuel prices; expectations that

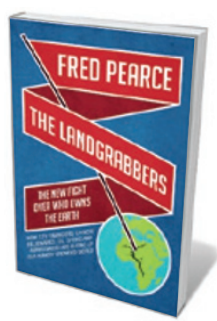

The Landgrabbers: The New Fight Over Who Owns the Earth FRED PEARCE Beacon/Eden 2012. 336/400 pp. $\$ 27.90 / £ 20$ agricultural and energy commodities will soon become scarce, given that known land and oil reserves are likely to run out within decades; rising demand for grain and meat; enhanced opportunities and incentives for financial speculation; and concerns about Project Books: global environmental degradation and species loss. The hunt is on for access to land.

To find out who is behind the land deals, Pearce travelled the world for a year, investigating transactions and interviewing buyers, sellers, local community members, government officials, law students and conservation scientists. He draws on his own experience as well as a range of research (including papers from an April 2011 conference in Brighton, UK, which I co-organized as part of the Land Deals Politics Initiative).

Pearce's focus on buyers and their financial or corporate lineages is what sets The Landgrabbers apart. They make up an extraordinary group: asset strippers, Saudi Arabian sheiks, a "self-styled wild man of Wall Street”, Christian evangelists, venture capitalists, White Russian nobles, agricultural ministers and clothing tycoons turned conservationists. Pearce documents the lofty ambitions and near-missionary zeal that drive buyers to snap up land everywhere from the semi-arid, sparsely populated Paraguayan Chaco to potential crop fields in war-torn South Sudan.

What emerges is paradoxical. On the one hand, as Pearce shows, land deals are backed by a wide variety of intentions, some of them good. There are deals intended to help Africans to develop a modern, profitable agricultural sector; to grow rice or oil palm; to build game parks from Kenya to Cambodia; to preserve land in Patagonia; and to provide South African farmers with land in Mozambique, Zambia and Georgia. $\rightarrow$ NATURE.COM

To read about the links between oil and poverty, see: go.nature.com/nk7emp 
On the other hand, most of the deals tend to leave local people worse off, without rights to the land they have worked for generations and without access to shelter, jobs or natural resources. Pearce illustrates this point with many examples, including Dominion Farms, which he says is draining productive wetlands in western Kenya to grow rice, using chemicals that pollute the Yala River and providing only a fraction of the promised jobs - while prohibiting locals from hunting and fishing. Although the World Bank insists that land deals can be win-win for buyers and locals, most land grabbers are motivated by the bottom line. Their underlying goals are to provide benefits for an external community, through commodity production, mineral or fossil-fuel extraction or environmental protection. As Pearce points out, buyers tend to make ambitious promises that rarely come true, and land grabs seem to exacerbate the economic and social inequalities that make them possible in the first place.

Pearce leaves some questions unanswered. He does not explain how 'land grabs' should be defined: does any purchase constitute grabbing? And how different are today's acquisitions from colonization and the 'scramble for Africa' more than a century ago? Is it possible that the international community has learned enough to stop the worst abuses of land grabbing?

The World Bank has proposed a set of voluntary principles that would counsel land grabbers to be more humane, but these have met with scepticism. Olivier De Schutter, the UN special rapporteur on the right to food, has likened such principles to pretending that "destruction of the global peasantry" can be done responsibly. But there has also been a sustained effort by social movements and the Food and Agriculture Organization of the United Nations to publicize an alternative, human-rights-based approach to land access, beginning not with how to feed and fuel the world, but rather with how to improve the well-being of people living in poverty.

Those efforts, says Pearce, could promote a future reliant on sustainable, efficient production from smallholdings. There is ample evidence that a growing world population would be better fed by improving the yields of those already on the land than by introducing largescale, energy-intensive industrial farming. And then all we would need to 'grab' would be a cup of shade-grown coffee - and a little room for the coffin that Tolstoy mentioned.

Wendy Wolford is a professor of development sociology at Cornell University in Ithaca, New York, and a founding member of the Land Deals Politics Initiative at the International Institute of Social Studies of Erasmus University Rotterdam in the Netherlands.

e-mail:www43@cornell.edu

\section{Books in brief}

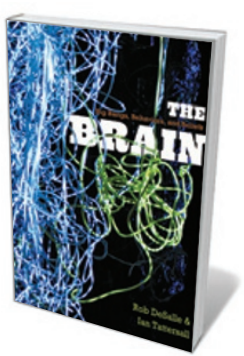

The Brain: Big Bangs, Behaviors, and Beliefs

Rob DeSalle and lan Tattersall YALE UnIV. PRESS 320 pp. £29.95 (2012)

Dream-weaver, computer, "evolutionary mess": however we view the human brain, thinking about thinking never palls. Here, two eminent curators from New York's American Museum of Natural History anthropologist lan Tattersall and genomicist Rob DeSalle — cherrypick the latest research in evolutionary biology, molecular biology and neuroscience to fashion a considered take on why humans have reached cognitive supremacy. The resulting brainfest covers the Big Bang, the evolution of nervous systems, the senses, data processing, emotions, memory, language, behaviour and more.

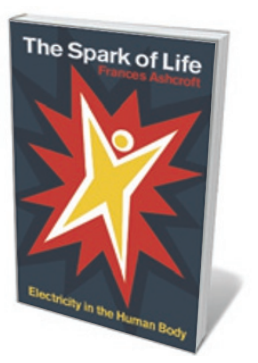

The Spark of Life: Electricity in the Human Body

Frances Ashcroft AlLEN LANE 352 pp. £25 (2012)

Physiologist Frances Ashcroft celebrates the "body electric" animal electricity - in this interweaving of research breakthroughs, science history and human stories. Membrane proteins found in all cells, known as ion channels, produce electrical signals that control processes including the human heartbeat, vision and sexual attraction through electrical 'events' in neurons and muscle cells. Ion channels also have a role in insulin secretion, and among her fascinating offerings, Ashcroft recounts how her own findings in this area have improved treatment of a rare genetic form of diabetes.

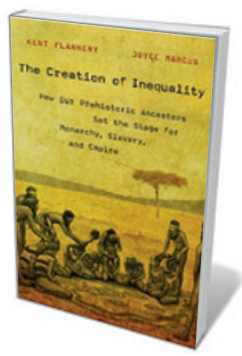

The Creation of Inequality: How Our Prehistoric Ancestors Set the Stage for Monarchy, Slavery, and Empire

Kent Flannery and Joyce Marcus HARVARD UNIV. PRESS 544 pp. $£ 29.95$ (2012)

The extreme disparities in prosperity and status that plague societies and spawn empires had their roots 4,500 years ago, argue anthropological archaeologists Kent Flannery and Joyce Marcus. Drawing on ethnography and archaeology, they reveal how societies create elites and tyrants. High rank for the ambitious and talented, for instance, becomes problematic when translated into hereditary rights, and competition among the privileged can lead to despotism.

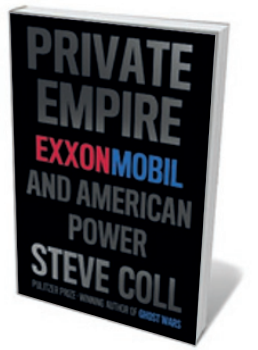

Private Empire: ExxonMobil and American Power

Steve Coll PenGUIN 704 pp. \$36 (2012)

Oil giants don't come much bigger than ExxonMobil or, claims Pulitzer-prizewinning journalist Steve Coll, more secrecy-shrouded. On the basis of more than 400 interviews, Coll explores the years from the 1989 Exxon Valdez oil spill to 2011 - a period when the business's net cash flow was, he says, US\$493 billion - and tracks ExxonMobil's accrual of power, from Equatorial Guinea and Iraq to its Texas headquarters. A vast cast, including world leaders, corporate scientists and influential former chief executive Lee Raymond, enriches the deeply researched proceedings.

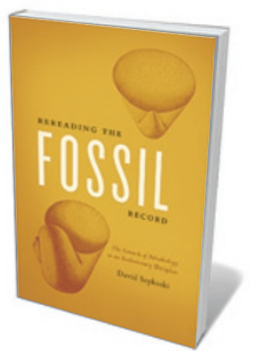

Rereading the Fossil Record: The Growth of Paleobiology as an Evolutionary Discipline

David Sepkoski UnIV. CHICAGo PRESS 440 pp. \$55 (2012)

In the 1970s, a new kid on the block was shaking up palaeontology, geology and biology. Historian David Sepkoski charts the rise of palaeobiology from 1945 to 1985 , driven by a small but illustrious band of palaeontologists including Stephen Jay Gould and David Raup, who grappled with how the geological record could produce evidence for evolution. The solution, as Sepkoski engagingly relates, lay in quantitative analysis of evolutionary patterns in fossils. 